defect over right thigh with exposed femoral artery pseudoaneurysm in a 23-year-old male who suffered electric burn with $1100 \mathrm{~V}$ alternating current and was referred to our centre after 40 days. Due to high voltage electric current injury, local tissue was deficient as donor, with debribed and fibrosed gracilis, tensor fascia lata and sartorius muscles and surrounding raw area. Options to cover the exposed femoral artery [Figure 1] which had a history of blowout were either a complicated microvascular free flap or morbid inferiorly based rectus abdominis muscle/myocutaneous flap.

We used this flap as a simple alternative in given scenario against complex tissue transfer. A femoral angiography was done to confirm the diagnosis of pseudoaneurysm [Figure 2], whichwas repaired with venous patch and subsequently covered it with a preputial flap. The arterial supply reaching the outer preputial layer fold by $180^{\circ}$ to supply the inner layer and it ultimately terminates at the corona. Blood supply to the prepuce reaches via 4 to 5 minute vessels, distributed both ventrally and dorsally. ${ }^{[1,2]}$

Unfurling of the prepuce can be easily done by giving an incision on the inner layer, near the corona circumferentially, and carefully dissecting the 2 layers of the prepuce without damaging the blood supply to either.

A dorsal slit was given up to the base of glans. Incision was then turned perpendicular and was taken all around, leaving $1 \mathrm{~cm}$ skin attached on each side of the frenulum [Figure 3]. This unfurled prepuce was then used to cover the raw area above the freshly repaired artery. Base of flap was attached in a manner that almost

\title{
Novel use of preputial flap
}

Sir,

The novel use of prepuce as a regional flap to cover a

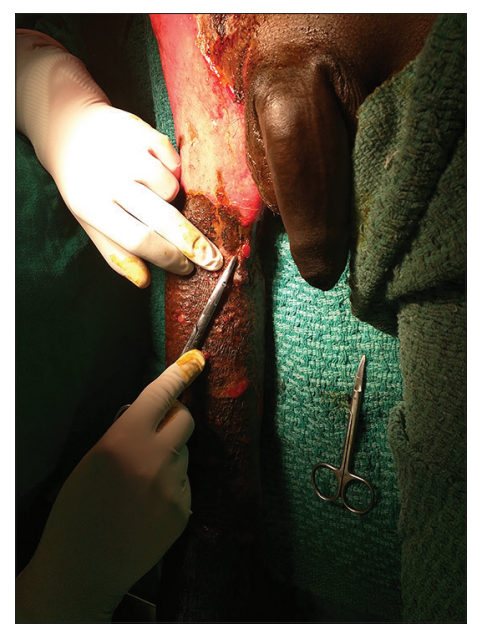

Figure 1: Exposed femoral artery pseudoaneurysm with grafted surrounding skin and raw areas. Deficient local tissues for cover 


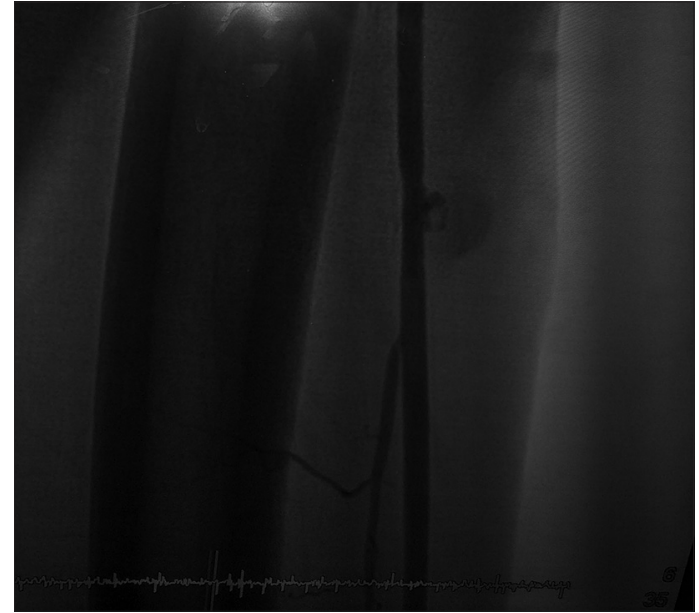

Figure 2: Arteriography showing the pseudoaneurysm pre-operatively

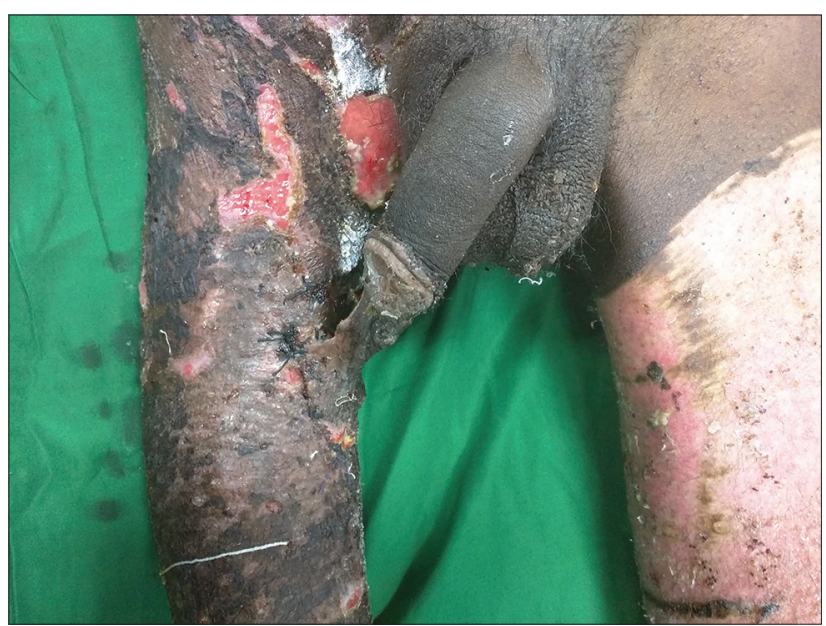

Figure 4: Attached preputial flap covering the repaired femoral artery

$100 \%$ cover was achieved [Figure 4]. Post-operatively, the patient was kept sedated to avoid erection. Flap was detached on $21^{\text {st }}$ post-operative day [Figure 5].

Special care is taken in preputial flap to prevent acute kinking and detachment during penile erection as pedicle of flap is attached with the corona. Dimensions possible with this flap are up to $8 \mathrm{~cm} \times 10 \mathrm{~cm}$, but it will vary with the amount of prepuce available with the individual..$^{[3]}$ It can be used as a distant flap to cover fingers and wrist or as an adjunct to a groin flap. ${ }^{[3,4]}$ In the areas in the radius of penile length, it can be used as a regional flap as shown in this article.

\section{Financial support and sponsorship} Nil.

\section{Conflicts of interest}

There are no conflicts of interest.

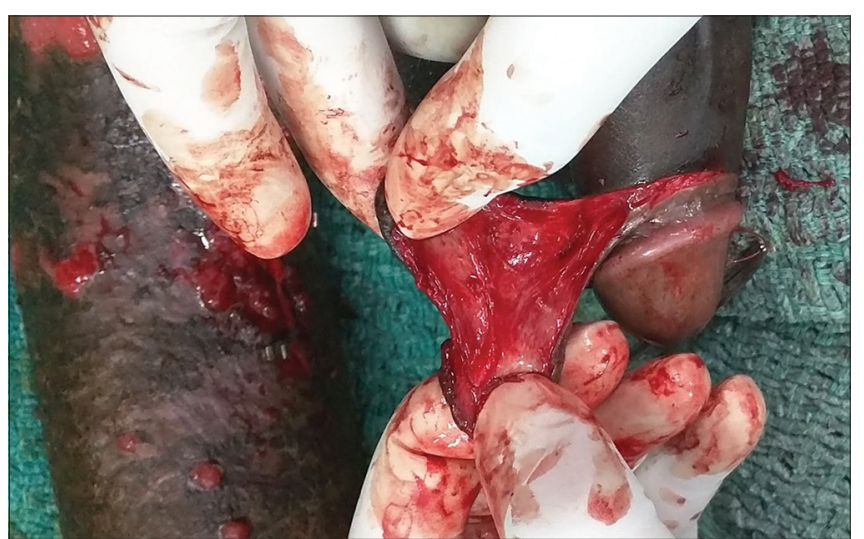

Figure 3: Preputial flap raised

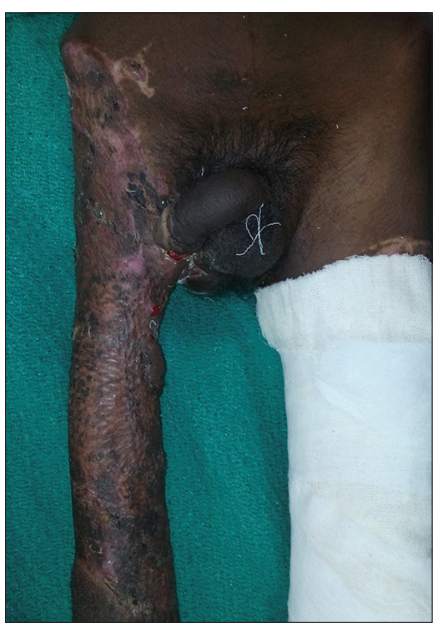

Figure 5: Post-operative after detachment of flap and inset

Ankit Gupta, Shyam Gupta, Akhil Kumar, Manoj Kumar Jha, Sameek Bhattacharaya, Vinay Kumar Tiwari

Department of Burns, Plastic and Maxillofacial Surgery, PGIMER and RML Hospital, New Delhi, India

Address for correspondence: Dr. Ankit Gupta, Department of Burns, Plastic and Maxillofacial Surgery, PGIMER and RML Hospital, New Delhi, India.

E-mail: drankit1612@yahoo.com

\section{REFERENCES}

1. Hinman F Jr. The blood supply to preputial island flaps. J Urol 1991;145:1232-5.

2. Juskiewenski S, Vaysse $\mathrm{PH}$, Moscovici J, Hammoudi S, Bouissou E. A study of the arterial blood supply to the penis. Anat Clin 1982; 4: $101-7$.

3. Tiwari VK, Sarabahi S, Chauhan S. Preputial flap as an adjunct to groin flap for the coverage of electrical burns in the hand. Burns 2014;40:e4-7.

4. Sharma D, Tiwari VK. Preputial flap to hand and forearm. $\mathrm{Br} \mathrm{J}$ Plast Surg 2000;53:635-6. 
This is an open access article distributed under the terms of the Creative Commons Attribution-NonCommercial-ShareAlike 3.0 License, which allows others to remix, tweak, and build upon the work non-commercially, as long as the author is credited and the new creations are licensed under the identical terms.

\begin{tabular}{|l|l|}
\hline \multicolumn{2}{|c|}{ Access this article online } \\
\hline Quick Response Code: & Website: \\
\hline & www.ijps.org \\
\cline { 2 - 2 } & Dol: \\
\hline
\end{tabular}

How to cite this article: Gupta A, Gupta S, Kumar A, Jha MK, Bhattacharaya S, Tiwari VK. Novel use of preputial flap. Indian J Plast Surg 2017;50:112-4. 